\title{
Third-Party Intervention and the Preservation of Bargaining Relationships
}

\author{
Bradley R. Weinberg, Ph.D. \\ Assistant Professor of Industrial Relations \\ Robert Sutherland Hall \\ Queen's University \\ Kingston, Ontario, Canada K7L 3N6 \\ (343) 540-9644 \\ bw81@queensu.ca
}

Abstract: This article uses longitudinal contact data to examine if third-party dispute resolution procedures available in Ontario improve the health of bargaining relationships and contribute to their preservation. It performs this in two manners: (1) using survival analysis to see how the mechanisms correlate with the likelihood of relationship dissolution and (2) using dynamic panel models to observe their state dependence. The latter is undertaken to see if third-party intervention pushes the parties to settle subsequent agreements earlier in the process - a finding that would reveal another aspect of relationship preservation if those earlier interventions are shown to correlate with lower likelihoods of dissolution. While the survival analysis does show that the earlier procedures in the dispute resolution process associate with lower likelihoods of dissolution than later ones, the dynamic panel model estimates do not indicate that third-party intervention induces voluntary or even earlier settlements in subsequent rounds of bargaining. Keywords: Collective Bargaining; Dispute Resolution; Survival Analysis; Dynamic Panel Models

Acknowledgements: I would like to thank Alex Colvin, Adam Seth Litwin, Chris Riddell and Samuel Kleiner for their helpful comments. I would also like to thank the staff at the Ontario Ministry of Labour, especially Katherine Waterhouse, for providing me with access to much of the data that was used in this paper and for answering all accompanying questions about it. Finally, I am very grateful to Mark Gough for assisting with the data. The data in this paper may be obtained from the respective governmental agencies. The statistical programs are available from the author upon request. 
In the field of industrial relations, there is a longstanding adage that mediation is the most widely used, but the least researched form of third-party dispute resolution (Devinatz and Budd 1997). While this adage may not hold outside of industrial relations given the proliferation of studies on mediation in other areas of conflict research, it is still perhaps the case within it. Much of the industrial relations literature on dispute resolution has concentrated on strikes and compulsory arbitration. Strikes inflict costs on the parties for continued disagreement that pushes the parties to compromise to achieve a settlement whereas arbitration imposes the settlement on the parties through a ruling issued by a third party. The goal of both of these is indisputably the resolution of the dispute through settlement. This has led to a focus on settlements as the primary outcome of dispute resolution mechanisms, but depending on which procedure is in operation, settlement may not be the only goal.

With regard to third-party dispute resolution (of which strikes would be excluded), arbitration is often conceptualized as a procedure that exhibits low third-party control over the process, but high third-party control over the outcome. This is in contrast to mediation, the process by which a third party attempts to facilitate an agreement but does not have the power to impose one. This is seen as a procedure having high third-party control over the process, but low third-party control over the outcome (Lewicki et al. 1992). While this distinction may not be quite as clear-cut as the typology suggests, it indicates that while the resolution of an impasse remains a goal of mediation, it is not the only one. With its focus on the bargaining process, rather than the outcome, through bringing the parties together to facilitate a settlement, mediation has been viewed as a means to foster healthy bargaining relationships (Devinatz and Budd 1997). However, and this is perhaps due to the preponderance of studies on work stoppages and arbitration, the mediation literature in industrial relations has largely focused on settlements as 
the primary measurement of outcomes rather than this goal of improving relationships. This is in spite of numerous studies of mediation in other contexts, such as marital divorce, parental custody, and other legal disputes, that have shown that mediation can improve the relationship between disputing parties (Wall and Lynn 1993).

This study undertakes an investigation of this alternative goal by exploring whether dispute resolution procedures, and mediation in particular, improves the health of bargaining relationships and contributes to their preservation. The examination of this research question will be undertaken in two ways. First, it will utilize survival analysis to see how the various dispute resolution mechanisms correlate with the likelihood of relationship dissolution. This will seek to establish whether certain forms of dispute resolution, particularly those that are thought to improve the relationship, correlate with a lesser likelihood of relationship dissolution compared to the other impasse procedures available and compared to voluntarily settled agreements. Second, it will use a criterion that is pervasive in the literature examining the effectiveness of dispute resolution procedures: their ability to induce voluntary settlements. This will be investigated in the same manner as which the narcotic effect, or rather state dependence, of impasse procedures has been tested involving arbitration in the public sector and strike incidence in the private sector. If earlier stages of settlement are shown to correlate with better relationship survival, then showing that previous use of third-party intervention induces settlements at earlier stages of the process in subsequent negotiations, through a negative state dependence, would also be evidence of a form of relationship preservation.

Using microdata of private sector non-construction bargaining relationships in Ontario that began during the period 1985 to 2012, this study finds mixed results for whether dispute resolution procedures improve the health of bargaining relationships and, therefore, contribute to 
their preservation. The survival analysis does produce some interesting evidence in that it shows that mediated agreements correlate with a lower likelihood of relationship dissolution than agreements settled through either conciliation or work stoppages. Further, mediated agreements correlate with a similar or only slightly higher likelihood of dissolution as compared to voluntarily negotiated agreements settled directly by the parties. However, the analysis of the usage of third-party dispute resolution procedures over time using dynamic panel data models indicate that they do not induce voluntary settlements, or even push settlements to earlier stages in the process, the result that one might expect given the notion that certain dispute resolution procedures may improve the health of bargaining relationships.

\section{Literature Review}

Given the principle of free collective bargaining underlying North American industrial relations, directly negotiated voluntary agreements settled between the parties in a bargaining relationship are traditionally seen as preferable to those produced with the involvement of a third party. Voluntary agreements, the product of the joint decision making of the parties, are thought to have a higher likelihood of acceptance and endurance than agreements that involve a third party, particularly those in which the agreement is imposed (McCormack 1991; Budd et al. 2017). This is because the parties themselves are more likely to understand their own needs and wants, and therefore, produce the compromises that can best fit their particular situation than can someone external to the relationship (McCormack, 1991; Farber and Katz 1979). However, collective bargaining is an inherently conflictual process and so third-party intervention is often available as a means to help parties overcome their disputes when an impasse is reached. Given the aforementioned preference for voluntary agreements, it is generally believed that the 
influence of third parties should be minimized in the collective bargaining process whenever possible and should encourage the settlement of voluntary agreements. Further, the concern that the parties to a bargaining relationship may come to rely on third-party dispute resolution procedures when they have access to them, diminishing their ability to resolve their own disputes, has led to much scholarly attention on the effect that such procedures may have on the bargaining process and bargaining relationships. This is particularly true in the public sector where in many jurisdictions the services provided by a number of occupations are deemed essential such that the right to strike has been replaced by a third-party dispute resolution mechanism. The concern that the impasse resolution procedure will induce a reliance on it over time, known as the "narcotic effect," has been examined by observing how the probability of settlement or settlement rate changes across rounds of bargaining (Anderson 1981).

Interestingly, none of the studies that investigate the narcotic effect examine whether or not the impasse procedures under study influence the mortality of the relationships. This may be because the analysis is longitudinal and, therefore, assumes that the relationships will persist, regardless of impasse or the manner in which it is resolved. This is perhaps not surprising for the studies that investigate the state dependence of compulsory arbitration since all of these studies draw upon public sector relationships where dissolution is much less prevalent than in the private sector. However, for the studies that examine strike incidence, this is perhaps somewhat surprising since work stoppages are highly conflictual occurrences that one might think may endanger the viability of a bargaining relationship. To my knowledge, the only state dependence study that mentions how their sample changes over time is Campolieti et al. (2005). They cite that smaller bargaining units tended to drop out of their sample over time, the cause of which they do not mention, but one would presume is due to the relationships ending. Since their focus 
is strike incidence and duration, though, rather than relationship dissolution, there is no investigation as to whether the strikes are responsible for the disappearance of the relationships. Even outside of this state dependence literature, there has been very little investigation into how dispute resolution mechanisms associate with relationship dissolution. Strike incidence has been shown to significantly increase the probability of decertification (Ahlburg and Dworkin 1984), but this finding involves only one manner in which relationships may end and one form of dispute resolution. There doesn't appear to be any studies that examine how conciliation, mediation or arbitration associates with the likelihood that a relationship will dissolve.

This article represents the first to investigate how the various dispute resolution procedures, particularly those that involve a third party, correlate with bargaining relationship dissolution. Due to the use of data on private-sector relationships in the province of Ontario, this study may have little to say about arbitration as it is rarely used in this sector (less than 1 percent of the agreements in the main sample were settled using arbitration). In contrast, the other forms of third-party intervention offered in Ontario, conciliation and mediation, are utilized quite frequently (responsible for the settlement of 26 and 20 percent of the agreements in the main sample respectively). Historically, the distinction between these two interventions is defined by how actively the third party participates in the process. In conciliation, the conciliator plays a passive role whose mere purpose is to bring the two sides back to the bargaining table to continue negotiations, whereas in mediation, the mediator plays a more active role of facilitating the negotiations by suggesting compromises and settlements. However, in practice there is often little difference between the two such that the terms may be used interchangeably (Rehmus 1965; Devinatz and Budd 1997). In speaking with the Ministry of Labour’s Dispute Resolution Services, this was corroborated as it was stated that there was no functional difference between 
the practice of conciliation and mediation. However, they do represent different stages within the Ontario dispute resolution procedure (see Figure 1 for a diagram of the procedure), which means that while their practice may not be differentiable, they do take place in slightly different contexts and may represent varied levels of conflict.

\section{[[Figure 1 about here.]]}

Ontario has a compulsory conciliation requirement in which the Ministry of Labour (MOL) appoints a conciliation officer to assist the parties come to agreement if either of the parties requests it. This is generally the first step in the dispute resolution process in the private sector of Ontario and it must be undertaken in order to enter into a legal strike/lockout position. There is no obligation for how intensely the parties participate in conciliation; the parties are required to be present for at least one meeting once they enter this stage, but they can withdraw following it. If conciliation is unsuccessful then this begins a countdown upon which at its expiration, either party may commence a work stoppage. Following conciliation, the MOL appoints a mediator to assist the parties but he/she is only used if both parties voluntarily agree to participate in mediation. If mediation is used following conciliation ${ }^{1}$, then it takes place within the context of the aforementioned countdown that enables the parties to undertake a work stoppage. Given that mediation is voluntary, though, means that not all of the relationships that proceed to the terminal step in the procedure use mediation as an intermediate step. Regardless of whether the parties undertake mediation, once the countdown following conciliation has expired, then the parties may enter into a work stoppage, representing the terminal step in the

\footnotetext{
${ }^{1}$ Parties may undertake mediation on their own volition, such that it can take place and effectuate an agreement without either of the other two stages. However, it was stated that while this was a possibility, it was rare in practice and that the process generally follows the order outlined above. Other procedures, such as fact-finding or arbitration, may also be undertaken if voluntarily agreed to by both of the parties, but these other procedures are rare in this setting.
} 
procedure. Thus, one might expect that as relationships move into later stages of the procedure, representing potentially higher levels of conflict, then these subsequent procedures may increasingly correlate with relationship dissolution. However, the effectiveness of the procedures with regard to the preservation of bargaining relationships may be moderated by the context in which they are situated (mandatory vs. voluntary, legal vs. illegal strike positions). This is essentially an empirical question that this study seeks to investigate below.

For the studies that examine the usage of dispute resolution procedures over time, much of the theory underlying the existence of a narcotic effect stems from learning effects developed by the negotiators in a relationship. Initially, for arbitration regimes, this resulted in the hypothesis that the use of arbitration in one round will result in increased use in future rounds as the parties learn that disputes can be settled easily and at less cost through the imposition of an arbitration award rather than through either a work stoppage (if a choice was available) or the trouble of difficult collective bargaining. This assumes that the contract awarded by the arbitrator, often thought to be the difference between the two final offers in conventional arbitration, is acceptable to the parties (Anderson 1981). Other models of arbitration and other explanations for the existence of the narcotic effect have also been postulated. Farber and Katz (1979) developed a model of arbitration in which the parties are assumed to be risk averse and therefore are induced to voluntarily settle agreements due to the uncertainty surrounding an arbitrator's award. However, as parties continue to use arbitration, and therefore learn about the process and the arbitrator, the uncertainty concerning arbitration may be reduced such that usage of the procedure may increase over time. "Face-saving” or a principle-agent problem have also been proffered as potential explanations for why there might be an increase in the use of arbitration over time (Stevens 1966; McCall 1990). In this case, it is hypothesized that 
negotiators will increasingly use arbitration for political reasons as it allows them to place the blame of a bad bargain on the arbitrator.

While all of the aforementioned predict an increase in usage over time, the half-life effect predicts that usage rates will decline. This hypothesis is also based on learning, but without the assumption that the arbitration awards are acceptable. Essentially, if the parties are unhappy with the outcome of arbitration then this can be viewed as an additional cost imposed on the parties that may be avoided through direct negotiations. It may also be that bargaining pairs are willing to try a new dispute resolution procedure after its enactment, but may become disenchanted with its outcomes such that the usage rate declines over time (Anderson and Kochan 1977; Butler and Ehrenberg 1981). Similarly, the state dependence literature with regard to strikes theorized that strikes in the past influenced the probability of strikes in the present due to learning effects. Mauro (1982) postulated that strikes are the result of miscalculation between the bargaining pairs and that strikes allow them to gain information that may be used to avoid such costly errors in the future, resulting in a negative state dependence or as Schnell and Gramm (1987) called it - "a teetotaler effect”.

The findings of the empirical literature investigating the existence of the narcotic effect for dispute resolution procedures are as varied as their theoretical underpinnings. Due to space constraints and the focus on conciliation/mediation, these empirical findings will not be recounted here, but it is important to note a debate that pervades this literature: the control of unobserved heterogeneity in the empirical analysis. Butler and Ehrenberg (1981) argue that there may be different predispositions towards the use of arbitration across bargaining units and that by not controlling for them, one cannot distinguish whether the increased impasse over time is due to prior impasses or the greater propensity for impasse in all rounds that might exist 
amongst bargaining units. Based upon this, most of the empirical studies since Butler and Ehrenberg (1981) have adopted a methodology that controls for unobserved heterogeneity across bargaining units and this study follows their lead.

The evidence of the existence of a narcotic effect with regard to arbitration and strikes is more developed than for other procedures, such as the intermediate stages of mediation and/or conciliation, simply due to the number of extant studies. This is somewhat surprising given the call for action by Butler and Ehrenberg (1981) in their concluding sentences in which they state that the methods outlined in their article can and should be used for investigating the narcotic effect with respect to any of the dispute resolution procedures. This combined with the recognition that mediation may improve the health of the relationship, implying that it might affect subsequent interactions, compounds the surprise that no one has heeded their call. It may be that mediation and conciliation has eluded investigation thus far due to their placement in the middle of the dispute resolution process or due to the fact that participation by the parties in these procedure are often voluntary, especially in the private sector (Devinatz and Budd 1997).

Given the above hypotheses for a narcotic/teetotaler effect for arbitration or strikes, it is reasonable to ask what state dependence we might expect to find with regard to mediation and conciliation given that they have not been adequately investigated. It seems highly likely that learning effects may also play a role in whether or not there is state dependence with regard to the intermediate stages. While they focused on the achievement of the settlement through mediation, Kochan and Jick (1978) did find that settlements tended to be concentrated among jurisdictions that likely had little experience with impasse resolution procedures. This leads them to suggest that the use of the procedure may lessen as the parties gain experience with it and perhaps discover its shortcomings, which would be indicative of a negative state dependence 
- a teetotaler or half-life effect. Gerhart and Drotning (1985) also suggest that it may be the acquisition of bargaining experience that leads to a decline in the use of mediation/conciliation as “two highly sophisticated negotiators need no impasse procedure at all[, t]hey can be their own mediators and factfinders” (p. 170). Finally, if mediation/conciliation actually do foster healthy relationships and are successful at not only settling the current impasse, but possibly preventing future ones as is predicted in the mediation literature outside of industrial relations (Wall and Lynn 1993), then this might lead us to observe a decrease in their usage over time.

It also seems plausible that some of the theories underlying a positive state dependence for the other procedures outlined above may potentially be applied to mediation and conciliation. Bargaining pairs could lose their ability to fashion their own agreements with continued use of such procedures. Indeed, Gerhart and Drotning (1985) present some anecdotal evidence to support such a hypothesis. The face-saving/principle agent problem identified above could also be at play as the negotiators, for reasons of ineptitude or politics, can place the blame of a bad bargain on the mediator/conciliator (Devinatz and Budd 1997). The cost of the procedures, at least relative to the terminal step of a work stoppage, could potentially result in a positive state dependence too. Anderson and Kochan (1977) found that mediation/conciliation was more effective at producing a settlement when a strike was the terminal step, rather than arbitration, which they liken to the difference in cost between the two final steps. With the high costs that a work stoppage imposes on the parties, bargaining pairs may be unwilling to go to the terminal step in successive negotiations, but may come to rely on the less-costly intermediate steps. Finally, how effective the parties find the procedure may have implications for any investigation of state dependence. If parties find the procedure to be effective, then it seems plausible that this may foster continued use of it. However, what the effect might be if the parties find the 
procedure to be ineffective is ambiguous, partially due to their being situated in the middle of the dispute resolution procedure. Parties who are dissatisfied with the outcomes at the intermediate stage could potentially settle at the earlier or later stages in future negotiations, possibly leading to a finding of positive, negative, or no state dependence (if there is no identifiable trend either way).

A few of the studies that examine the narcotic effect of dispute resolution procedures terminating in arbitration have attempted to incorporate intermediate steps into their analysis. This is usually performed through variations in their dependent variables and this approach provides some direction for this study. Anderson and Kochan (1977) used two dependent variables in their study, a binary variable for going to impasse and a categorical variable for the stage in the procedure in which the agreement was settled. Kochan and Baderschneider (1978) incorporate a third dependent binary variable into their study that indicated if the round of negotiation proceeded to the final step in the process. Chelius and Exejit (1985) also checked the robustness of their findings by varying their definition of impasse to include mediation in some specifications and exclude it in others. The estimates in these articles that investigate whether a narcotic effect exists when mediation and other intermediate steps are included as an impasse must incorporate the state dependence of these intermediate steps, if they exist, but they don't attempt to disentangle them. Further, none of these articles that vary their dependent variables account for the possible influence of unobserved heterogeneity such that one cannot rule out the possibility that their estimates are spurious. This study will attempt to disentangle the state dependence of the various steps in the impasse resolution procedure for private sector bargaining units in Ontario using the same techniques as the state dependence studies that account for unobserved heterogeneity. However, it will perform this on a variety of different 
dependent variables that measure if the current round of negotiations goes as far in the procedure as previous rounds. It is through a comparison of these estimates of previous impasse experience, in which different steps are considered as an impasse, that it will seek to make inferences about the narcotic effect of the different steps. In particular, it will focus on the intermediate steps that have heretofore not thoroughly been investigated and are theorized to potentially influence future outcomes. If it is shown in that the prior use of the intermediate stages push the parties to settle at earlier stages in subsequent agreements, and these earlier stages are shown to correlate with less dissolution, then this would give us a greater understanding of how third-party intervention preserves bargaining relationships.

\section{Data}

The core data used in this study is from the Ontario Ministry of Labour's Collective Bargaining Information Services (CBIS) database. This data set tracks bargaining relationships through the number of completed rounds of bargaining in the province of Ontario. Due to the focus on the duration and dissolution of bargaining relationships in the first portion of the analysis, only relationships that are observed from their origin can be included. This results in the use of the sample of 3,857 private sector non-construction bargaining relationships that started during the period 1985-2012 in the province of Ontario, which includes just over 14,000 collective agreements, in this first portion of the analysis. ${ }^{2}$ Since the focus of the second portion of the analysis shifts from the duration and dissolution of bargaining relationships to the usage of dispute resolution procedures over time, it is no longer necessary to exclude the relationships whose origin are unobserved. Thus, the second half of the analysis performs estimation using (1)

\footnotetext{
${ }^{2}$ Since this sample excludes relationships that were already in existence at the beginning of the timeframe for analysis, it can be thought of as a flow sample.
} 
the new relationship sample from the first portion of the analysis and (2) the larger sample of relationships including those already in existence in 1985. This latter sample is comprised of 9,764 private sector relationships and approximately 48,000 collective agreements. ${ }^{3}$

The main variables of interest in this study are a series of binary variables representing the manner in which the agreements are settled. These include if the agreements were settled through first contract arbitration, arbitration, mediation, conciliation or after having experienced a work stoppage. An agreement that is directly negotiated between the parties without the assistance of a third-party or a work stoppage is treated as the base case for the manner of settlement. Since these variables may also be viewed as proxies for conflict in the relationship, it is hypothesized that they will likely correlate with an increased risk of dissolution. Further, it is expected that those modes that are associated with higher levels of conflict and take place later in the process (e.g. FCA, arbitration, work stoppages) will be greater in magnitude than those associated with lower levels that take place earlier (e.g. conciliation or mediation). As mentioned above, the correlation between the manner in which agreements are settled and the likelihood of relationship dissolution has yet to be examined. Next, these variables and their lags are used to construct the dependent variables (detailed in the methods section) to investigate the state dependence of the dispute resolution procedures in the second portion of the analysis.

Beyond these main variables of interest, there are a number of unit-specific independent variables included in the analysis that control for other factors that may influence the likelihood of dissolution or impasse (or both). Using data from the Ontario Labour Relations Board's monthly Reports, dummy variables for the incidence of unfair labor practice (ULP) charge filings and first contract arbitration (FCA) application filings that take place prior to the first

\footnotetext{
${ }^{3}$ The smaller sample is referred to as the MOL/OLRB merged data sample, whereas the larger sample is referred to solely as the MOL data sample in the regression tables below.
} 
agreement within a relationship are included as independent variables. These two variables indicate whether a relationship began under turbulent circumstances where the employer may have opposed the decision of his/her workforce to unionize and therefore, should identify relationships that are more conflictual.

Two independent variables related to the size of the bargaining unit are included as control variables. Studies show that larger bargaining units are less likely to decertify (see for example Dickens et al. 1987; Meyer and Bain 1994), which may be due to a variety of reasons. These potentially include the support given to larger units due to their importance to the union (Chafetz and Fraser 1979), the resources they can draw upon through affiliations with a national union or union federation (Meyer and Bain 1994), or their greater bargaining power (Bain 1981). However, bargaining unit size has been shown to positively correlate with going to impasse and strike incidence (Anderson and Kochan 1977; Swidinsky and Vanderkamp 1982; Campolieti et al 2005), so it hypothesized that this variable will positively correlate with the usage of the dispute resolution procedures. The dynamics of the size of the bargaining unit is incorporated as a control through the inclusion of the percent change in the size of the bargaining unit from the prior round of negotiation to the current round. According to Campolieti et al. (2005), this variable "provide[s] a firm-specific measure of changing circumstances, which may also capture some business cycle effects” (p. 612). Thus, this variable may proxy for the economic state of the firm and the movement of labor into or out of the bargaining unit within the company. A decrease in the size of the bargaining unit could indicate that the health of the firm is diminishing or it could be that the firm is shifting resources elsewhere, perhaps to escape the bargaining relationship. 
The length of the prior contract has also been shown to influence the likelihood of strike incidence (Card 1988; Campolieti et al. 2005). Thus, using a one-year agreement as the base case, dummy variables for two-year agreements and agreements of greater than two years duration are included in the second portion of the analysis. ${ }^{4}$ The employment status of the workers in the bargaining unit is also included in the estimation. Using a base case of a bargaining unit with only full-time employees, binary variables for part-time bargaining units, full-/part-time mixed units, and bargaining units in which part-time workers are not specifically excluded are incorporated. Part-time workers may be less attached to their job, which means that bargaining units including part-time employees may experience higher turnover and be at a greater risk of relationship dissolution. In terms of dispute resolution usage, these variables may proxy for solidarity within bargaining units as part-time only or full-time only units may have more unified interests. Campolieti et al. (2005) hypothesized that this would result in a greater likelihood that those bargaining units would strike. Thus, units that include only one type of worker may positively correlate with dispute resolution usage.

Finally, dummy variables for the union, industry, region, calendar year and cohort are included in various specifications to control for any effects pertaining to these characteristics of the bargaining relationships. The industry dummies are based on the one-digit SIC 1980 codes, while the region dummies are based on the economic regions specified in the CBIS database. The inclusion of the cohort effects serves two purposes: (1) they provide a control for the macroeconomic environment for the year in which the relationship started and (2) they ensure

\footnotetext{
${ }^{4}$ Since agreements don't strictly adhere to year lengths and can include fractions of a year, the construction of these dummy variables for the prior contract length is as follows: the one-year dummy variable includes all agreements less than 18 months in duration; the two-year dummy variable includes all agreements greater than 18 months but less than 30 months in duration; and the greater than two years dummy is all agreements greater than 30 months in duration.
} 
that the duration of the relationship is independent of the entry and censoring time (Wooldridge 2002).

The remainder of the independent variables investigates the impact of various aspects of the external environment. The political environment is controlled for through the inclusion dummy variables for the political party that forms the government in power. This variable is a proxy for the favorability of the climate in the province towards organized labor. It has been shown that the party in power, through its enactment of legislation, appointments to the Labour Relations Board, and its rhetoric either highlighting the positives or negatives of organized labor, can affect the certification and decertification activity within a province (Martinello 2000). The legal environment is controlled for using dummy variables for the four substantial revisions made to the Ontario Labour Relations Act (OLRA) during the period of study, taking place in 1986, 1993, 1995, and 2000 respectively. ${ }^{5}$ With the exception of changes to the type of first contract arbitration in operation in the province, these legal revisions did not greatly change the dispute resolution procedure. This stability in the dispute resolution process should be perhaps viewed as an asset as Farber and Katz (1979) highlight that changes to the dispute resolution procedure have an effect on negotiated settlements that make the investigation of any such changes difficult to assess. The last external covariate is meant to control for the economic environment through the inclusion of the provincial unemployment rate. Table 1 below provides summary statistics for the variables used in the analysis.

\section{[[Table 1 about here.]]}

\footnotetext{
${ }^{5}$ The bargaining relationships are classified based upon the legal regime in which the relationships began. Thus, if the relationship began under the OLRA 1993, then it is coded as belonging to the OLRA 1993 legal regime, even if it persists beyond the OLRA revision in 1995. This seems to be a rather intuitive approach as many of the policy changes, such as mandatory representation vote legislation and first contract arbitration, deal with the early stages of the unionization process and are less likely to impact renewal agreements and existing relationships.
} 


\section{Methods}

\section{Dispute Resolution Procedures and Relationship Dissolution}

Since this study aims to investigate how the various dispute resolution procedures associate with the likelihood of relationship dissolution, an event occurrence, the first portion of the study uses survival analysis. Within this method, there are two forms of estimation, the choice of which often depends on how one views the process that is being studied. If it is believed that the event of interest occurs as part of a continuous process, meaning that the event of interest can take place at any point in time, then the continuous-time approach should be adopted. However, if the event of interest can only occur at discrete points in time or if its exact timing is unknown, but is known to have taken place within an interval of time, then the discretetime approach should be undertaken (Singer and Willett 2003). Given the different manners in which relationships may come to an end, the choice between the two approaches is not entirely clear within this context. There is a conceptual argument to be made that the dissolution of relationships may be better represented through the discrete approach as some forms of dissolution are more likely to take place at the conclusion of a contract, such as decertifications and voluntary terminations since applications for them can only be made during the "open periods" of a contract. However, this only applies to the application whereas the actual decertification or termination may take place at any point in time after such an application. Further, events that may change the nature of the bargaining relationships, such as work stoppages or perhaps contentious bargaining itself, coincide with rounds of negotiation, which may further undergird the use of the discrete approach. Conversely, business closures may take place at any time, perhaps pointing towards the continuous approach, but even this is not without caveats as in the case where the parties signed a closure agreement. This would make the closure 
appear in the data as having taken place at the end of a contract. Due to these difficulties, it was decided that both approaches would be explored.

The continuous-time approach is undertaken first using the Cox regression model (Cox 1974), which allows one to investigate the influence of covariates without imposing a specific distribution on the baseline hazard function. Thus, this model doesn't estimate the influence of time, or rather duration dependence, on the likelihood of relationship dissolution, but treats it as a nuisance parameter that is cancelled out of estimation (Cleves et al. 2004). This avoids the possibly adverse effects that imposing the wrong baseline hazard may have on the estimated coefficients. The Cox model is given by

$$
h\left(t \mid \boldsymbol{X}_{j}\right)=h_{0}(t) \exp \left(\boldsymbol{X}(\mathrm{t})_{j} \boldsymbol{\beta}_{x}\right)
$$

where the hazard rate for subject $j$ is determined by the baseline hazard, $h_{0}(\mathrm{t})$, multiplied by the exponentiation of a vector of covariates, $\mathbf{X}(\mathrm{t})$, and a vector of estimated regression coefficients, $\boldsymbol{\beta}_{\boldsymbol{x}}$. The study then shifts to the discrete-time approach and uses the logistic regression function in estimation, which is given by

$$
h_{i j}=1 /\left[1+\exp \left(-\alpha_{j}-\boldsymbol{\beta}^{\prime} \boldsymbol{X}_{i j}\right)\right]
$$

or in logit form

$$
\log \left(\frac{h_{i j}}{1-h_{i j}}\right)=a_{j}+\boldsymbol{\beta}^{\prime} \boldsymbol{X}_{\boldsymbol{i} \boldsymbol{j}}
$$

where $h_{i j}$ is the discrete-time hazard rate, $\alpha_{j}$ is a constant or vector of constants, $x_{i j}$ is a vector of covariates and $\beta$ is a vector of regression coefficients. Switching to the discrete-time approach may be an improvement over the continuous-time approach if the discrete intervals represent a good approximation of the underlying process and if little information is lost by switching (BoxSteffensmeier and Jones 1997). While the former will be investigated below through a variation in the units of analysis time, the latter requirement would seem to be met since the independent 
variables largely vary with the bargaining round (for unit characteristics) and year (for the external environment), leading to little loss of information by the switch.

Another advantage within the discrete-time approach is that the influence of time may be easily and flexibly estimated through the inclusion of a vector of dummy variables representing each of the discrete-time periods. As stated above, there is perhaps some conceptual appeal to using the rounds of bargaining as the unit of analysis time, but given that the duration of contracts are determined by the parties, this poses a problem in that the interval length won't be uniform across relationships. Thus, when rounds of bargaining are used as the unit of analysis, the study follows Allison's (2010) advice and directly controls for interval length by including it as an independent variable. The other problem with using the bargaining round as the unit of analysis time is that contracts are relatively long in duration (the average contract duration in the data is approximately 2.5 years), which means that if the underlying process is truly continuous, then the discrete-time approach with widely-spaced intervals may be inappropriate. To see how sensitive the estimation is to the use of bargaining rounds as the unit of analysis time, the study also undertakes the analysis using years as the unit of analysis time. Finally, similar to the discussion above concerning the effect of unobserved heterogeneity on the usage of arbitration or strike incidence, unobserved heterogeneity may also influence the likelihood of relationship dissolution. If unobserved heterogeneity, often referred to as "frailty" in the survival literature, is not controlled for in the estimation then this might bias the coefficients of the other independent variables, leading to spurious conclusions. Thus, a random effect that is assumed to be normally distributed with variance $\sigma^{2}$ is included in some of the specifications to test for the presence of unobserved heterogeneity and to investigate how this influences the estimated coefficients. 


\section{Dispute Resolution Procedure State Dependence}

The second portion of the analysis uses dynamic panel data models to investigate whether or not there is state dependence with respect to the various forms of dispute resolution procedures, meaning whether current usage is correlated with prior usage. The basic model to be estimated in a dynamic model is given by

$$
y_{i t}=\emptyset_{1} y_{i t-1}+\cdots+\emptyset_{p} y_{i t-p}+\boldsymbol{\beta}^{\prime} \boldsymbol{X}_{i t}+\alpha_{i}+\varepsilon_{i t}
$$

where $y_{i t}$ is a binary dependent variable that indicates the use of a dispute resolution procedure for unit $i$ in bargaining round $t$, the $y_{i t-1}, \ldots, y_{i t-p}$ represent lagged dependent variables from the previous rounds of negotiation, the $\varphi_{1} \ldots \varphi_{p}$ are estimated coefficients on the lagged dependent variables, $\boldsymbol{X}_{\boldsymbol{i}}$ is a vector of covariates, $\boldsymbol{\beta}$ is a vector of estimated regression coefficients, $\boldsymbol{a}_{i}$ is a fixed or random effect meant to control for unobserved heterogeneity, and $\varepsilon_{i t}$ is the error term. Positive estimates on the lagged dependent variable coefficients would indicate that there is positive state dependence whereas negative coefficients would indicate negative state dependence. If the $a_{i}$ are treated as fixed effects, allowing them to be correlated with the regressors, and estimation is performed using dummy variables for each unit then the above model produces inconsistent estimates as the first demeaned lagged dependent variable will be correlated with the demeaned error term. Similarly, inconsistent estimates are produced if the estimation is performed through first-differencing as the differenced lagged dependent variable is correlated with the differenced error term (Cameron and Trivedi 2009). However, Anderson and Hsiao (1981) show that consistent estimates may be produced using instrumental variable estimation in which the twice lagged dependent variable is used as an instrument for the differenced lagged dependent variable since the former is uncorrelated with the differenced error term. This panel data fixed effect linear probability model is the same method as was used in a number of empirical articles investigating state dependence under an arbitration regime (Butler 
and Ehrenberg 1981; Currie 1989) and strike incidence (Schnell and Gramm 1987; Campolieti et al. 2005; Campolieti 2015).

Where this study differs from its predecessors is through the variation in how the dependent variable of dispute resolution procedure usage is defined. Whilst all of the studies in the literature review describe the various stages of the dispute resolution procedure, the majority of them investigate only one dependent variable, usually a binary variable that encompasses all of the procedures (so impasse vs. no impasse) or the terminal step (usually strikes in the private sector or arbitration/fact-finding in the public sector). Those that do vary their dependent variables don't attempt to control for unobserved heterogeneity such that their findings may be spurious. By controlling for both unobserved heterogeneity and varying the definition of the dependent variable, this study attempts to disentangle the state dependence for the various dispute resolution procedures.

Each of the dependent variables will examine the state dependence that is associated with going to a certain stage in the process, given that they went at least as far in the process in prior round(s) of negotiation. Thus, the first dependent variable that will be investigated is the state dependence of the terminal step in the dispute resolution procedure in the private sector of Ontario: the strike. Next, the dependent variable will be defined as a binary variable for if the negotiation went to impasse, or rather used any type of third-party intervention, versus no impasse in which the agreement was settled through voluntary, direct negotiations. It is through a comparison of the estimates using these two dependent variables, where the former is analogous to a baseline, that the state dependence of the intermediate procedures will initially be investigated. For example, if it is found that there is negative state dependence for the incidence of a strike and if the estimate for the state dependence on the impasse dependent variable is 
positive (or more negative) then it can be inferred that the state dependence for the intermediate procedures are positive (or negative). Finally, since the CBIS database notes how each of the agreements are settled, a dependent variable that denotes if the negotiations went to mediation or beyond (thus omitting settlements in conciliation) is created to attempt to disentangle the state dependence that is associated with each of the intermediate procedures. However, as stated above, since relationships may not move through the same sequence of stages, caution may need to be exercised in interpreting the findings of this last dependent variable. Thus, the most informative comparison may be between the estimates for the state dependence of a strike versus the state dependence of impasse, even if the latter one conflates the state dependence among conciliation, mediation and strikes.

\section{Results}

\section{Dispute Resolution Procedure and Relationship Dissolution}

\section{[[Table 2 about here.]]}

Table 2 presents the estimates of the survival analysis used to investigate how the different manners of dispute resolution associate with the likelihood of relationship dissolution. The first column of estimates assumes a continuous-time process with days as the unit of analysis time and uses a Cox regression model to investigate the influence of the covariates. The estimates reported in this column are the exponentiated regression coefficients, known as hazard rate ratios, which can be interpreted as the percentage difference in the likelihood of the event of interest given a one unit change in the value of the covariate. Thus, within this context, a risk ratio above (below) 1 corresponds with an increase (decrease) in the likelihood of dissolution, and therefore a decrease (increase) in the duration of the relationship, whereas a ratio of 1 indicates no influence on the likelihood of dissolution due to the corresponding covariate. The 
remaining columns in Table 2 transition to the discrete-time approach using a logit model with either bargaining rounds (specifications 2-4) or years (specifications 5-7) as the unit of analysis time. These columns also report exponentiated coefficients, which can be interpreted in a similar manner as the hazard ratios in column (1), but these figures represent odds ratios. Further, within the different measures of duration, the specifications differ based upon the inclusion of dummy variables to control for the influence of time and a heterogeneity distribution to control for unobserved heterogeneity.

As one can see from the table, the variables that control for the manner in which an agreement is settled largely exhibit what was hypothesized. Those dispute resolution procedures that take place later in the process, and therefore would likely involve higher levels of conflict, associate with a greater likelihood of relationship dissolution as compared to the base case of a directly-negotiated agreement. In terms of the terminal steps of the process, the incidence of a work stoppage statistically significantly correlates with a nearly 54 percent increase in the likelihood of relationship dissolution for the round of bargaining/contract settlement in which it occurs. The use of arbitration correlates with an approximate 41 percent increase in the likelihood of dissolution, but it is statistically insignificant. The imprecision of the arbitration estimate is probably related to the rarity with which arbitration is used in the private sector. An agreement that is imposed through first contact arbitration (FCA) associates with a 178 percent increase in the likelihood of dissolution, an estimate that is statistically significant at the 1 percent level. With regard to the intermediate steps, both mediation and conciliation associate with a lesser likelihood of relationship dissolution than those mechanisms already mentioned, but they don't adhere to the trend in which successive stages of the process correlate with an increasing hazard of dissolution. Conciliation, generally the first step in the process, statistically 
significantly associates with a 36 percent increase in the likelihood that the relationship will come to an end during the interval produced by that round of bargaining. This contrasts rather markedly with the marginally significant estimate of a nearly 12 percent increase in the likelihood of dissolution that associates with an agreement settled through mediation. The finding that mediation is more effective than conciliation at preserving the bargaining relationship is interesting, especially since the two, as practiced by the Ministry of Labour, are largely the same procedure. The difference in these estimates could potentially be due to the circumstances through which the parties access them (i.e. voluntary vs. mandatory, in a legal work stoppage position vs. not in a legal position) - a point that will be discussed further below. Moving from the continuous-time approach in specification (1) to the discrete-time approach in specification (2) in which the bargaining rounds are used as the unit of analysis time, one can see that each of the covariates generally produce coefficients that are qualitatively similar to the prior ones, in terms of direction and statistical significance, but that they tend to differ quantitatively as the magnitude of the estimates are somewhat larger. Specification (2) doesn't control for either duration dependence or unobserved heterogeneity though, which were two reasons given above for undertaking the discrete-time approach. Specification (3) adds bargaining round dummy variables to flexibly control for duration dependence ${ }^{6}$, while specification (4) additionally controls for unobserved heterogeneity by introducing a random effect. Wald tests of the joint significance of the bargaining round dummy variables indicate that there is statistically significant duration dependence. While the estimates are sensitive to the

\footnotetext{
${ }^{6}$ In order to estimate a covariate in the discrete-time approach using a logit model, there needs to be events and nonevents within that cell. In later rounds of bargaining, there are drastically less relationships due to the failure of relationships in prior rounds and/or due to censoring. Thus, the specifications that seek to control for the baseline hazard include dummy variables for each of the first nine rounds of bargaining and then dummy variables for rounds 10-12 and rounds 13-15. While there are relationships in the data that successfully complete up to 20 rounds of bargaining, there are no relationships that experience dissolution beyond round 15 .
} 
inclusion of the bargaining round dummy variables and the random effect, the conclusions that can be drawn across them (and the continuous-time estimates) remain largely the same. However, there are a couple of differences worth noting, the most important of which to this study is the loss of significance for the coefficient for agreements that are settled through mediation. This suggests that an agreement that is settled through mediation has a statistically indistinguishable association with the likelihood of relationship dissolution as one that it is settled directly by the parties without the aid of a third-party.

The final three columns in Table 2 are meant as a check on how sensitive the estimates are to the use of bargaining rounds as the unit of analysis time. These three specifications mimic the prior three with the stepwise inclusion of controls for the baseline hazard and unobserved heterogeneity, except that bargaining rounds are replaced by years as the unit of analysis time. Since the influence of duration dependence and unobserved heterogeneity is shown to be statistically significant, the final column is used as the preferred specification with respect to these three. As one can see, these estimates are different from their predecessors in a number of respects, which may suggest that they are sensitive to the manner in which analysis time is defined. $^{7}$ In terms of the manners in which agreements may be settled, the conclusions remain largely the same as in the prior estimates, but the associations for agreements settled through work stoppages, first contract arbitration and mediation are larger, while those for arbitration and

\footnotetext{
${ }^{7}$ Since the data is structured based upon settled agreements that can span multiple years, the transition to using years as the unit of analysis time requires that the observations be split (i.e. a three year contract becomes three observations - hence the increase in the sample size). This is not without its shortcomings, though, as agreements can span any duration, meaning a decision has to be made concerning agreements that include fractions of a year. It was decided that if an agreement was settled in a given year of a relationship that the bargaining round-level time-varying covariates would take the values of the subsequent agreement. For example, if the parties to a relationship settled two and a half year agreements in its first two rounds of bargaining then the values of the bargaining round covariates would take the values of the latter agreement in year 3 . Thus, the difference in the estimates across the use of bargaining rounds and years may partially reflect this difference in addition to those listed in the text.
} 
conciliation are smaller. The level of significance increases for all of those that increased in magnitude, including the coefficient for mediation returns to marginal significance at the 10 percent level, while the level decreased for those that diminished in magnitude. Thus, while the use of years as the unit of analysis time slightly decreases the confidence with which one can say that third-party intervention preserves bargaining relationships due to the increased magnitude with which some of the various methods of settlement associate with relationship dissolution, it still shows that there are better chances at survival for those that settle earlier in the process. It also shows that mediation, in this context, produces outcomes that appears to be comparable to voluntarily-settled agreements or only slightly worse.

\section{Dispute Resolution Procedure State Dependence}

Table 3 provides the estimates of the fixed effects linear probability models using the instrumental variable method suggested by Anderson and Hsiao (1981) to investigate the state dependence of the various dispute resolution procedures in operation in the private sector of Ontario. Due to the first-differencing used in this portion of the analysis, any time-invariant covariates are dropped. The first three columns in Table 3 use only the relationships that were included in the survival analysis performed above. However, since the overall duration of the relationship doesn't need to be observed to perform this analysis, the latter three columns use all of the available private-sector relationships from the CBIS database, including those already in existence in 1985 and those that enter the dataset with a "renewal agreement". ${ }^{8}$ Within these groupings, the specifications differ based upon how the dependent variable is defined. Specifications (1) and (4) use the incidence of a work stoppage as the dependent variable.

\footnotetext{
${ }^{8}$ A relationship can begin with a "renewal agreement" when the Ministry of Labor has no record of the prior agreements within that relationship.
} 
Specifications (2) and (5) use the incidence of an impasse as the dependent variable, which is defined as the use of any dispute resolution mechanism and therefore includes all agreements that were not settled voluntarily by the parties. Specifications (3) and (6) define the dependent variable as those agreements that are settled by either a work stoppage or mediation.

\section{[[Table 3 about here.]]}

When the estimation is restricted to only those relationships that were used in the survival analysis, the lag of the dependent variable for the incidence of a strike indicates that there is no statistically significant state dependence. By this estimate, a strike in the prior round of negotiations has no significant influence on the likelihood of a strike in the current round. When the dependent variable is extended to include all forms of dispute resolution, though, the lag of this impasse dependent variable is both positive and highly statistically significant. If the parties to a relationship went to impasse in the prior round of bargaining, then this estimate suggests that the probability that the parties will go to impasse in the current round is 0.07 higher. Thus, there does appear to be a positive state dependence to the use of dispute resolution procedures, but given the difference between these two estimates, one would infer that the dependence is driven by the intermediate stages. When the dependent variable is redefined to only include work stoppages and mediation, essentially omitting conciliation which is generally the first step in the dispute resolution procedure, the lag of this dependent variable is also highly statistically significant and positive. In fact, it is larger in magnitude than the prior estimate for impasse, suggesting that it is potentially the mediation stage that is largely responsible for this estimate. This portends that if the prior round of bargaining went to mediation or a work stoppage, then the probability that the parties will go at least that far in the process in the current round increases by 0.08. When the number of relationships used in the estimation is expanded to include all 
relationships in the private sector that were in existence at the start of the period of analysis in specifications (4)-(6), the same conclusions can be drawn. ${ }^{9}$

Finally, many of the state dependence articles on arbitration and strikes incorporate further lags of the dependent variable to see if additional bargaining rounds in the history of a unit predict current usage of the dispute resolution procedure under investigation. Table 4 below includes such an analysis by including a second lag of the various dependent variables that were examined in this study. The results of the estimation for work stoppages indicates that if the bargaining unit had a work stoppage two bargaining rounds ago, then this associates with an increased probability of a work stoppage in the current round of 0.04 , but this is only marginally statistically significant at the 10 percent level. Furthermore, this finding does not hold when using the expanded dataset so it appears that this finding should be interpreted with caution. Interestingly, both the first and second lags of the work stoppage/mediation variables are positive and statistically significant for both the MOL/OLRB merged data and the expanded MOL data. These estimates indicate that if the bargaining unit went at least as far as mediation in both of the prior two rounds of negotiation then this associates with an increased probability of 0.28 and 0.25 for the two datasets respectively. Both of the lagged dependent variables for going to impasse using the larger MOL data are also statistically significant, indicating that if the unit went to impasse in each of the prior two rounds then this associates with an increased probability of 0.16 in the current round of bargaining. Thus, it appears that there may be some evidence that

\footnotetext{
${ }^{9}$ As shown in Campolieti (2015), there are a number of models that can be used for estimating state dependence, which may serve as robustness checks for one's preferred technique. Following his lead, the robustness of the results in Table 3 were checked by employing two other estimators: (1) the Arellano and Bond (1991) general method of moments fixed effects linear probability model and (2) a dynamic panel random effects probit estimator that uses the Wooldridge (2005) method to correct for the initial conditions problem. The results from these estimators produce the same conclusions as those found in Table 3, although the estimates differ slightly in magnitude. The lone exception to this is an estimated statistically significant negative state dependence for work stoppages when using the larger MOL sample. These estimates can be obtained from the author by request.
} 
the positive state dependence of the intermediate stages of the dispute resolution procedure in the private sector of Ontario extends beyond the influence of only the prior round of negotiation.

\section{[[Table 4 about here.]]}

\section{Discussion and Conclusion}

This study was undertaken with the goal of investigating whether or not dispute resolution procedures, and in particular those that are hypothesized to potentially improve the relationship between the parties of a bargaining relationship, are successful at preserving those relationships. This initially involved examining how the dispute resolution procedures associated with the likelihood of relationship dissolution during the interval, or rather the contract, that followed a round of bargaining. It was hypothesized that each successive stage of the dispute resolution procedure would correlate with an increase in the likelihood of dissolution as more conflictual relationships would progress to the later stages of the procedure. Interestingly, while it was found that the terminal step of a work stoppage did correlate with a greater likelihood of dissolution than the first step of conciliation, the intermediate step of mediation was found to correlate with the best survival experience among the dispute resolution procedures. In fact, by some estimates, depending upon how the unit of analysis time was defined, the likelihood of relationship dissolution for an agreement that was settled through mediation was statistically insignificantly distinguishable from a contract that was settled directly by the parties without the help of a third party. This finding that mediation associates with a better survival experience than conciliation is somewhat surprising since the practice of conciliation and mediation are identical in this setting. While the assertion that mediation (and perhaps also conciliation if there truly is no practical difference) may improve the health of a 
bargaining relationship has been made within the field of industrial relations, it was heretofore untested. This finding perhaps provides some evidence that mediation does improves the health of relationships.

This finding may need to be tempered though as it may point to the influence of the context in which relationships undertake either of these procedures, a point that has been made in other studies on dispute resolution. For example, it has been found that mediation is more effective at producing settlements when the terminal step of the impasse procedure is a work stoppage rather than arbitration (Anderson and Kochan 1977) or arbitration rather than factfinding (Kochan and Jick 1978). The fact that mediation in the private sector of Ontario generally occurs contemporaneously with a countdown to a legal strike position may add to the costs of failing to achieve a settlement in mediation as it may result in the parties progressing to a work stoppage. This same pressure is absent during conciliation as the countdown towards a legal strike position only begins upon the decision that conciliation can no longer progress the parties in bargaining, meaning after that stage. Likewise, the voluntary nature of mediation means that there may be a selection effect into the procedure by mature parties who understand its value, which may produce results that overstate the true effectiveness of mediation. Indeed, mediation has been shown to be more effective in contexts in which the parties have a greater desire for a settlement and when both sides buy into it (Wall and Lynn 1993), each of which would seemingly fit into this context. These same arguments can potentially be made with regard to conciliation and how the estimates of the effectiveness of that procedure may be understated here. Not only does it lack the added costs/pressure that may accompany failure as is found with mediation, but it can also be accessed by the parties if only one of them requests it, rather than both, meaning that the participation of one party may be forced. Lastly, since 
conciliation is mandatory in order to get into a legal strike position, some parties may undertake it only for that end result, which may lessen its effectiveness. While these estimates are important as they are the first to examine the effectiveness of dispute resolution procedures in preserving relationships, the above highlight the caution that should be made in trying to generalize these findings outside of the private sector of Ontario. This also highlights the need for future research to investigate how these dispute resolution procedures associate with relationship dissolution in other contexts (i.e. the public sector) or other jurisdictions (i.e. provinces, states or countries).

The second stage of the analysis involved an examination of the use of dispute resolution procedures over time as it was hypothesized that if the dispute resolution procedures actually did improve the health of relationships, then this might manifest itself as a decrease in their usage. This shifting of the parties towards settlements earlier in the procedure could also be thought of as a form of bargaining relationship preservation, especially if those earlier stages, as was shown in the first part of the analysis, associated with a lesser likelihood of dissolution. This hypothesis, however, doesn't appear to be supported by the estimates. While the incidence of a work stoppage in the prior round of bargaining was generally shown to have no association with the likelihood of a work stoppage in the current round, it was shown that the incidence of impasse in the prior round of bargaining statistically significantly correlated with an increase in impasse in the current round. A comparison of the coefficients produced by these two dependent variables leads one to infer that the estimate for the previous incidence of impasse is likely driven by the conciliation and mediation stages of the process. When the dependent variable was defined such that it only included mediation and work stoppages, essentially omitting settlements that occur during the initial conciliation stage, then this produced estimates that were similar, 
albeit slightly larger, than those found using the dependent variable with all of the procedures. This implies that it may actually be the mediation stage that is responsible for the positive state dependency. These findings are robust across a number of different estimators and a variation in the sample of data used in estimation. Furthermore, there is evidence that multiple prior rounds of bargaining may influence the outcomes in the current round such that the likelihood of impasse, when defined with either the inclusion or exclusion of conciliation, is compounded when impasse occurred in the prior two rounds of bargaining.

This continued use of impasse resolution procedures may indicate that there is a narcotic effect among bargaining units that use them. There were a number of suggestions provided above for why one might find a positive state dependency for mediation. It could be that negotiators are using mediators in a "face-saving” manner to absolve themselves of poor bargains or through learning effects in which the parties find mediation to be effective and are satisfied with its outcomes, leading them to return to it. Unfortunately, given the administrative data that is used here, this study cannot assess whether it is either of these explanations that are driving the estimates. Given what we know about the dispute resolution procedure in the private sector of Ontario though, the relative costs of the procedures certainly seem like a plausible explanation for the different estimates. The fact that mediation generally takes place immediately prior to the work stoppage stage, in the midst of a countdown to a legal strike position, may result in a trend in which the parties push the negotiations to the furthest low-cost stage, but are unwilling to bear the relatively higher costs of a work stoppage. It is important to note, though, that these estimates could also be indicative of unobserved differences between bargaining units, although all of the estimates regarding impasse procedure usage above attempted to control for such unobserved heterogeneity. If this unobserved heterogeneity is not 
sufficiently controlled for then these results may potentially identify relationships that are either more generally conflictual or conversely those that are more mature such that they understand the value of using mediation as a tool to achieve settlement.

However, given the results that suggest that the mediation stage may be the procedure that is driving the estimated positive state dependency, one may ask what the implications are of such a finding. Is a positive state dependency for the intermediate stages of the process harmful in some manner? The concern about the externalities that work stoppages and arbitration may harm the public would seem to be lessened, if non-existent, for mediation. It may be harmful if the intermediate stages actually push the parties further into the dispute resolution process. Nevertheless, it is worth highlighting that while many of the estimates that are produced above are statistically significant, the magnitudes of the coefficients are not tremendously large. Depending upon whether conciliation is included in the definition of impasse, the association of impasse in the prior round of bargaining to the current round is an increase in probability that ranges from 0.06 to 0.12 . There is some evidence though that more than the immediately prior round of negotiations may influence the likelihood of impasse in the current round. When the outcomes of the prior two rounds of negotiations are included in estimation, the compounding increase in the probability of impasse in the current round given impasse in the prior two rounds ranges from 0.16 to 0.28 . Future research should attempt to further investigate the effects that such dependence might have on the bargaining process to determine whether this represents an unacceptable increase in the usage of dispute resolution procedures that warrants potential policy action.

In the first of a series of decadal reviews of the mediation literature, it was highlighted that while research established that mediation was effective in the short-run, the same could not 
be said for the long-run and therefore this was identified as a fruitful area for future research (Wall and Lynn 1993). In that review, the authors note that while a number of studies show that the current relationship is improved by mediation, studies using evidence from community justice centers, divorce programs and international conflict indicate that mediation doesn't improve the relationship in the long-run. Thus, mediation was described as "a weak elixir for improving a dispute hostile enough to merit intervention by a third party” but that "[h]aving parties interact over and settle issues - with the assistance of a third party - does not automatically make them fond of each other" (Ibid, p. 177). By focusing on the intermediate stages of the dispute resolution procedure for bargaining relationships in the private sector of Ontario, this study has essentially taken steps to try to assess the long-run effectiveness of mediation, the findings of which must be said to be mixed. While prior studies of mediation in industrial relations examined the short-term effectiveness of mediation by focusing on the achievement of settlements, this study focused on the later outcomes of whether the relationships survive through the term of that agreed settlement and if it affects the negotiations of subsequent agreements. The results indicate that mediation is effective at preserving relationships in the former aspect as it associates with a likelihood of relationship dissolution that is lower than the other dispute resolution procedures and potentially comparable to voluntarily negotiated agreements. However, it is less effective in the latter aspect as it appears that mediation does not induce voluntary settlements in subsequent rounds of bargaining. In sum, it appears that mediation in the labor relations context may be the "weak elixir" that treats conflict, allowing the relationships to achieve a settlement and endure through that agreement, but that its remedy subsides by the time a new round of negotiations begins. 


\section{References}

Ahlburg, Dennis A., and James B. Dworkin. 1984. "The Influence of Macroeconomic Variables on the Probability of Union Decertification.” Journal of Labor Research, Vol. 5, No. 1, pp. 1428.

Allison, Paul D. 2010. Survival Analysis Using SAS: A Practical Guide, Second Edition. Cary, North Carolina: SAS Institute Inc.

Anderson, John C. 1981. "Determinants of Collective Bargaining Impasses: The Role of Dispute Resolution Procedures.” In Richard Peterson and Gerard Bomers, eds., Industrial Relations and Conflict Management. New York: Matinus Nijhoff.

Anderson, John C. and Thomas A. Kochan. 1977. "Impasse Procedures in the Canadian Federal Service: Effects on the Bargaining Process,” Industrial and Labor Relations Review 30 (April 1977), pp. 283-301.

Anderson, T.W. and Cheng Hsiao. 1981. "Estimation of Dynamic Models with Error Components.” Journal of the American Statistical Association, Vol. 76, No. 375, pp. 598-606.

Arellano, Manuel and Stephen Bond. 1991. "Some Tests of Specification for Panel Data: Monte Carlo Evidence and an Application to Employment Equations.” The Review of Economic Studies, Vol. 58, No. 2, pp. 277-297.

Bain, George Sayers. 1981. Certifications, First Agreements, and Decertifications: An Analytical Framework. Ottawa, Ontario: Ministry of Labour, Government of Canada.

Butler, Richard J. and Ronald G. Ehrenberg, "Estimating the Narcotic Effect of Public Sector Impasse Procedures,” Industrial and Labor Relations Review 35 (October 1981), pp. 3-20.

Box-Steffensmeier, Janet M. and Bradford S. Jones. 1997. "Time Is of the Essence: Event History Models in Political Science.” American Journal of Political Science, Vol. 41, No. 4, pp. 1414-1461.

Budd, John, Aaron Sojourner, and Jaewoo Jung. 2017. “Are Voluntary Agreements Better? Evidence from Baseball Arbitration.” Industrial and Labor Relations Review, Vol. 70, No. 4, pp. 865-893.

Cameron, A. Colin and Pravin K. Trivedi. 2009. Microeconometrics Using Stata. College Station, Texas: Stata Press.

Campolieti, Michele. 2015. "State Dependence in the incidence of strikes: Evidence from Canadian contract data using Heckman’s dynamic probit model.” Economic Letters, Vol 133, pp. 7-9. 
Campolieti, Michele, Robert Hebdon and Douglas Hyatt. 2005. "Strike Incidence and Strike Duration: Some Evidence from Ontario.” Industrial and Labor Relations Review, Vol. 58, No. 4, pp. 610-630.

Card, David. 1988. "Longitudinal Analysis of Strike Activity.” Journal of Labor Economics, Vol. 6, No. 2, pp. 147-176.

Chafetz, I. and C.R.P. Fraser. 1979. “Union Decertification: An Exploratory Analysis.” Industrial Relations, Vol. 18, No. 1, pp. 59-69.

Chelius, James R. and Marian M. Extejt, “The Narcotic Effect of Impasse Resolution Procedures,” Industrial and Labor Relations Review 38 (July 1985), pp. 629-38.

Cleves, Mario A., William W. Gould, and Roberto G. Gutierrez. 2004. An Introduction to Survival Analysis Using Stata. College Station, TX: Stata Press.

Currie, Janet. 1989. "Who Uses Interest Arbitration? The Case of British Columbia’s Teachers, 1947-1981,” Industrial and Labor Relations Review 42 (April 1989), pp. 363-79.

Devinatz, Victor G. and John W. Budd, “Third Party Dispute Resolution - Interest Disputes,” in David Lewin, Daniel J.B. Mitchell, and Mahmood A. Zaidi (eds.), The Human Resource Management Handbook Part II (Greenwich, CT: JAI Press, 1997), pp. 95-135.

Dickens, William T., Douglas R. Wholey, and James C. Robinson. 1987. "Correlates of Union Support in NLRB Elections.” Industrial Relations, Vol. 26, No. 3, pp. 240-252.

Farber, Henry S. and Harry C. Katz. 1979. "Interest Arbitration, Outcomes, and the Incentive to Bargain,” Industrial and Labor Relations Review 33 (October 1979), pp. 55-63.

Gerhart, Paul F. and John E. Drotning. 1985. “The Effectiveness of Public Impasse Procedures: A Six State Study.” Advances in Industrial and Labor Relations, Vol. 2, pp. 143-195.

Kochan, Thomas A. and Jean Baderschneider. 1978. "Dependence on Impasse Procedures: Police and Firefighters in New York State.” Industrial and Labor Relations Review, Vol. 31, No. 4, pp. 431-449.

Kochan, Thomas A. and Todd Jick. 1978. "The Public Sector Mediation Process: A Theory and Empirical Examination.” Journal of Conflict Resolution, Vol. 22(2), 209-240.

Lewicki, Roy J., Stephen E. Weiss and David Lewin. 1992. "Models of conflict, negotiation and third party intervention: A review and synthesis.” Journal of Organizational Behavior, Vol. 13(3), pp. 209-252.

Martinello, Felice. 2000. “Mr. Harris, Mr. Rae and Union Activity in Ontario.” Canadian Public Policy/Analyse de Politiques, Vol. 26, No. 1, pp. 17-33. 
Mauro, Martin J. 1982. "Strikes as a Result of Imperfect Information.” Industrial and Labor Relations Review, Vol. 35, No. 4, pp. 522-538.

McCall, Brian P. 1990. “Interest arbitration and the incentive to bargain: A principle-agent approach.” Journal of Conflict Resolution, Vol. 34, pp. 151-167.

Meyer, David and Trevor Bain. 1994. "Union Decertification Election Outcomes: Bargaining Unit Characteristics and Union Resources.” Journal of Labor Research, Vol. 15, No. 2, pp. 117136.

Ontario Labour Relations Board. January 1985-Decenber 2012. Ontario Labour Relations Board Reports. Toronto, ON: Government of Ontario.

Ontario Ministry of Labour. 2012. Collective Bargaining Information Services Database. Toronto, ON: Government of Ontario.

Rehmus, Charles M. 1965. "The mediation of industrial conflict: a note on the literature.” Conflict Resolution, Vol. 9, No. 1, pp. 118-126.

Schnell, John F. and Cynthia L. Gramm. 1987. "Learning by Striking: Estimates of the Teetotaler Effect.” Journal of Labor Economics, Vol. 5, No. 2, pp. 221-241.

Singer, Judith D. and John B. Willett. 2003. Applied Longitudinal Data Analysis: Modeling Change and Event Occurrence. New York, New York: Oxford University Press.

Stevens, Carl M. 1966. “Is Compulsory Arbitration Compatible with Bargaining?” Industrial Relations 5 (February 1966), pp. 38-52.

Swidinsky, Robert and John Vanderkamp. 1982. “A Micro-econometric Analysis of Strike Activity.” Journal of Labor Research, Vol. 3, No. 4, pp. 455-471.

Wall, Jr., James A and Ann Lynn. 1993. “Mediation: A Current Review.” Journal of Conflict Resolution, Vol. 37, No. 1, pp. 160-194.

Wooldridge, Jeffrey M. 2002. Econometric Analysis of Cross Section and Panel Data. Cambridge, Massachusetts: The MIT Press.

Wooldridge, Jeffrey M. 2005. "Simple Solutions to the Initial Conditions Problem in Dynamic, Nonlinear Panel Data Models with Unobserved Heterogeneity.” Journal of Applied Econometrics, Vol. 20, No. 1, pp. 39-54. 
Figure 1. Ontario Dispute Resolution Process

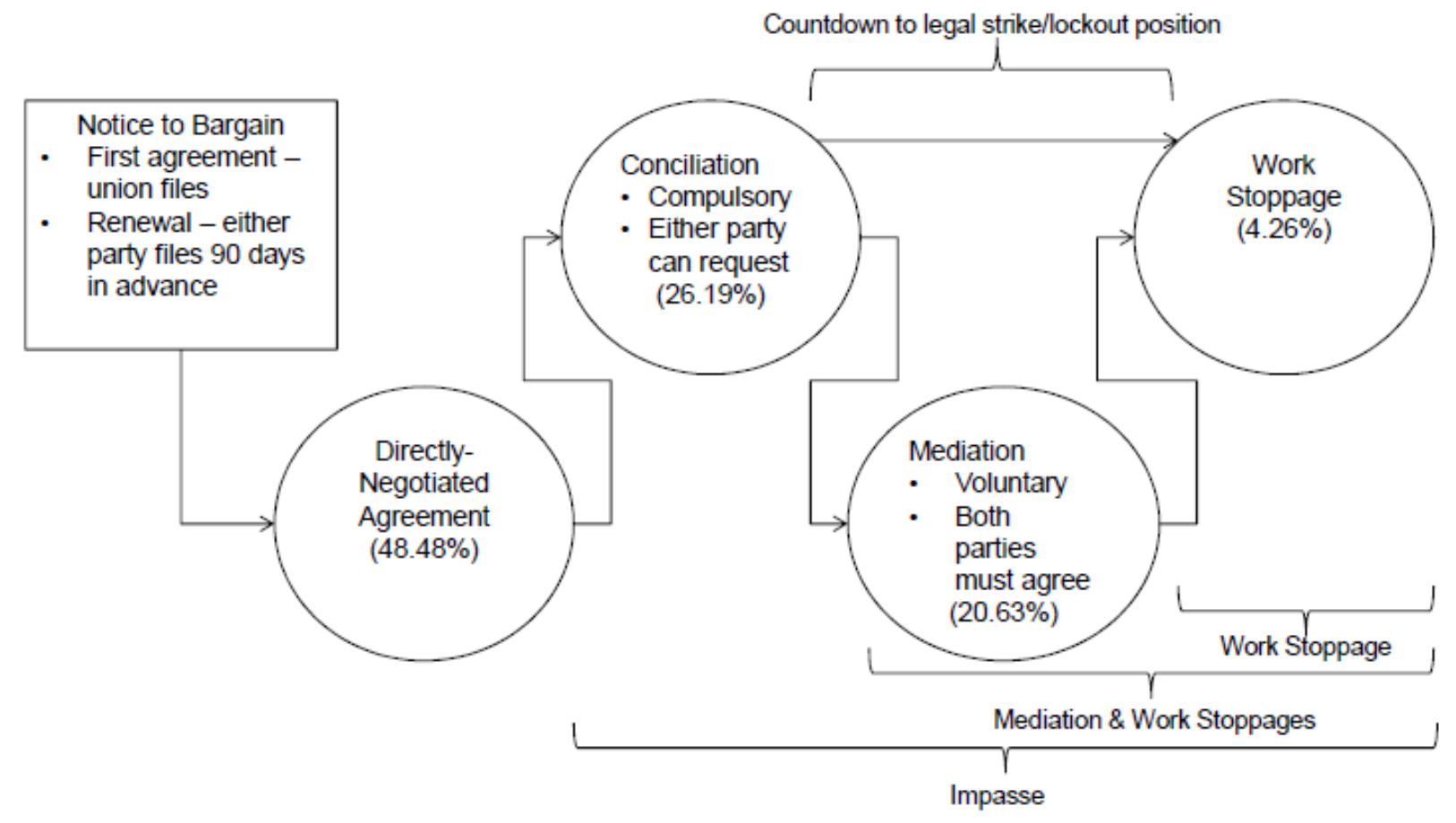

Note: The percentages shown refer to the percentage of agreements settled at that stage of the process in the merged MOL/OLRB data set for relationships that began during 1985-2012. The three downward facing brackets comprise the three dependent variables used in the analysis. 


\begin{tabular}{|c|c|c|c|c|c|c|c|c|c|}
\hline & \multicolumn{2}{|c|}{$\begin{array}{l}\text { Merged Dataset } \\
\text { (OML/OLRB) }\end{array}$} & \multicolumn{2}{|c|}{$\begin{array}{l}\text { Full Dataset } \\
\text { (OML only) }\end{array}$} & & \multicolumn{2}{|c|}{$\begin{array}{l}\text { Merged Dataset } \\
\text { (OML/OLRB) }\end{array}$} & \multicolumn{2}{|c|}{$\begin{array}{l}\text { Full Dataset } \\
\text { (OML only) }\end{array}$} \\
\hline & Mean & Std. Dev. & Mean & Std. Dev. & & Mean & Std. Dev. & Mean & Std. Dev. \\
\hline Manner of Settlement & & & & & Government in Power & & & & \\
\hline Work Stoppage & 0.042 & 0.200 & 0.043 & 0.202 & Conservative Party & 0.369 & 0.482 & 0.315 & 0.464 \\
\hline Arbitration & 0.004 & 0.061 & 0.002 & 0.045 & New Democratic Party & 0.178 & 0.383 & 0.213 & 0.410 \\
\hline First Contract Arbitration & 0.007 & 0.084 & 0.002 & 0.047 & Liberal Party (base) & 0.453 & 0.498 & 0.472 & 0.499 \\
\hline Mediation & 0.224 & 0.417 & 0.206 & 0.405 & & & & & \\
\hline Conciliation & 0.297 & 0.457 & 0.262 & 0.440 & Union & & & & \\
\hline Direct Bargaining (base) & 0.427 & 0.495 & 0.485 & 0.500 & $\begin{array}{l}\text { CUPE } \\
\text { UFCW }\end{array}$ & $\begin{array}{l}0.029 \\
0.142\end{array}$ & $\begin{array}{l}0.169 \\
0.349\end{array}$ & $\begin{array}{l}0.022 \\
0.099\end{array}$ & $\begin{array}{l}0.148 \\
0.299\end{array}$ \\
\hline Unfair Labor Practice Filing & 0.215 & 0.411 & & & SEIU & 0.035 & 0.184 & 0.024 & 0.153 \\
\hline First Contract Arbitration Application & 0.025 & 0.156 & & & CAW & 0.132 & 0.338 & 0.101 & 0.301 \\
\hline Bargaining Unit Size & 62.613 & 172.340 & 97.721 & 517.493 & OPSE & 0.006 & 0.079 & 0.004 & 0.059 \\
\hline Log Bargaining Unit Size & 3.224 & 1.306 & 3.368 & 1.441 & LIUNA & 0.113 & 0.317 & 0.056 & 0.229 \\
\hline \multirow[t]{2}{*}{ Change of Employment } & 1.385 & 57.823 & -1.821 & 133.493 & ONA & 0.002 & 0.045 & 0.001 & 0.028 \\
\hline & & & & & IBT & 0.101 & 0.302 & 0.100 & 0.300 \\
\hline Prior Contract Length & & & & & CEP & 0.049 & 0.215 & 0.044 & 0.205 \\
\hline 1 Year (base) & 0.080 & 0.271 & 0.103 & 0.304 & USW & 0.133 & 0.339 & 0.143 & 0.351 \\
\hline 2 Years & 0.208 & 0.406 & 0.342 & 0.474 & CLAC & 0.009 & 0.093 & 0.007 & 0.082 \\
\hline 2+ Years & 0.437 & 0.496 & 0.442 & 0.497 & HERE & 0.016 & 0.125 & 0.020 & 0.140 \\
\hline \multirow[t]{2}{*}{ Missing/Unknown } & 0.275 & 0.447 & 0.114 & 0.317 & RWDSU & 0.019 & 0.135 & 0.024 & 0.152 \\
\hline & & & & & GCU & 0.012 & 0.109 & 0.026 & 0.159 \\
\hline Type of Unit & & & & & IUOE & 0.017 & 0.127 & 0.022 & 0.146 \\
\hline Full-Time (base) & 0.146 & 0.353 & 0.169 & 0.375 & IBEW & 0.007 & 0.083 & 0.009 & 0.096 \\
\hline Part-Time & 0.017 & 0.128 & 0.016 & 0.126 & Other Union (base) & 0.179 & 0.384 & 0.299 & 0.458 \\
\hline Full-Time/Part-Time Mix & 0.150 & 0.357 & 0.121 & 0.326 & & & & & \\
\hline \multirow[t]{2}{*}{ Part-Time Not Excluded } & 0.687 & 0.464 & 0.694 & 0.461 & Industry (1980 SIC Codes) & & & & \\
\hline & & & & & Primary & 0.007 & 0.083 & 0.019 & 0.137 \\
\hline Legal & & & & & Manufacturing & 0.386 & 0.487 & 0.520 & 0.500 \\
\hline pre-1986 OLRA (base) & 0.084 & 0.277 & & & Transportation & 0.062 & 0.241 & 0.044 & 0.206 \\
\hline 1986 OLRA & 0.359 & 0.480 & & & Trade & 0.166 & 0.372 & 0.149 & 0.356 \\
\hline 1993 OLRA & 0.211 & 0.408 & & & Education & 0.009 & 0.097 & 0.006 & 0.078 \\
\hline 1995 OLRA & 0.181 & 0.385 & & & Health & 0.030 & 0.170 & 0.012 & 0.109 \\
\hline 2000 OLRA & 0.165 & 0.371 & & & Other Services & 0.341 & 0.474 & 0.249 & 0.433 \\
\hline Provincial Unemployment Rate & 7.558 & 1.526 & 7.525 & 1.663 & & & & & \\
\hline $\begin{array}{l}\text { Notes: The union abbreviations are as } \\
\text { (SEIU), Canadian Autoworkers (CAW } \\
\text { International Brotherhood of Teamster } \\
\text { Employees and Restaurant Employees } \\
\text { Operating Engineers (IUOE), Internati } \\
\text { from the author. Figures may not add }\end{array}$ & $\begin{array}{l}\text { anadian L } \\
\text { Public Se } \\
\text { ommunic } \\
\text { ERE), Ret } \\
\text { lerhood of } \\
\text { e to round }\end{array}$ & $\begin{array}{l}\text { iion of Publ } \\
\text { vice Employ } \\
\text { ions, Energ } \\
\text { il, Wholesal } \\
\text { Electrical W } \\
\text { ig. }\end{array}$ & $\begin{array}{l}\text { Ind Paper } \\
\text { \& Depart } \\
\text { kers (IBE }\end{array}$ & $\begin{array}{l}\text { (CUPE), Ur } \\
\text { PSE), Labor } \\
\text { orkers Unior } \\
\text { ent Store Un } \\
\text { ). Summar }\end{array}$ & $\begin{array}{l}\text { EP), United Steelworkers (US } \\
\text { (RWDSU), Graphic Commun } \\
\text { tistics for the year of settleme }\end{array}$ & $\begin{array}{l}\text { hristian La } \\
\text { ns Internati } \\
\text { the cohor }\end{array}$ & $\begin{array}{l}\text { ervice Em } \\
\text { Ontario Nu } \\
\text { ar Associa } \\
\text { l Union (C } \\
\text { fects are n }\end{array}$ & $\begin{array}{l}\text { Canada } \\
\text { Internat } \\
\text { d, but ca }\end{array}$ & $\begin{array}{l}\text { al Union } \\
\text { NA), } \\
\text { AC), Hotel } \\
\text { Union of } \\
\text { ained }\end{array}$ \\
\hline
\end{tabular}




\begin{tabular}{|c|c|c|c|c|c|c|c|}
\hline $\begin{array}{l}\text { Time: } \\
\text { Model: }\end{array}$ & $\begin{array}{l}\text { Continuous } \\
\text { Cox }\end{array}$ & $\begin{array}{c}\text { Discrete } \\
\text { Logit }\end{array}$ & $\begin{array}{l}\text { Discrete } \\
\text { Logit }\end{array}$ & $\begin{array}{l}\text { Discrete } \\
\text { Logit }\end{array}$ & $\begin{array}{c}\text { Discrete } \\
\text { Logit }\end{array}$ & $\begin{array}{c}\text { Discrete } \\
\text { Logit }\end{array}$ & $\begin{array}{c}\text { Discrete } \\
\text { Logit }\end{array}$ \\
\hline & (1) & (2) & (3) & (4) & (5) & (6) & (7) \\
\hline \multicolumn{8}{|c|}{ Manner of Settlement [Direct Bargain] } \\
\hline Work Stoppage & $\begin{array}{l}1.535^{* * *} \\
(4.19)\end{array}$ & $\begin{array}{l}1.736^{* * *} \\
(4.51)\end{array}$ & $\begin{array}{l}1.503^{* * *} \\
(3.30)\end{array}$ & $\begin{array}{l}1.503^{* * *} \\
(3.19)\end{array}$ & $\begin{array}{l}1.640^{* * *} \\
(4.80)\end{array}$ & $\begin{array}{l}1.619 * * * \\
(4.63)\end{array}$ & $\begin{array}{l}1.905^{* * *} \\
(4.32)\end{array}$ \\
\hline First Contract Arb. & $\begin{array}{l}2.780^{* * *} \\
(5.64)\end{array}$ & $\begin{array}{l}3.312^{* * *} \\
(4.78)\end{array}$ & $\begin{array}{l}2.323^{* * * *} \\
(3.35)\end{array}$ & $\begin{array}{l}2.341^{* * *} \\
(3.48)\end{array}$ & $\begin{array}{l}3.514^{* * *} \\
(7.06)\end{array}$ & $\begin{array}{l}4.163^{* * *} \\
(7.62)\end{array}$ & $\begin{array}{l}6.776^{* * *} \\
(5.98)\end{array}$ \\
\hline Arbitration & $\begin{array}{l}1.411 \\
(0.60)\end{array}$ & $\begin{array}{l}1.270 \\
(0.37)\end{array}$ & $\begin{array}{l}1.219 \\
(0.31)\end{array}$ & $\begin{array}{l}1.220 \\
(0.31)\end{array}$ & $\begin{array}{l}1.343 \\
(0.51)\end{array}$ & $\begin{array}{l}1.347 \\
(0.51)\end{array}$ & $\begin{array}{l}1.135 \\
(0.17)\end{array}$ \\
\hline Mediation & $\begin{array}{l}1.124^{*} \\
(1.72)\end{array}$ & $\begin{array}{l}1.133 \\
(1.59)\end{array}$ & $\begin{array}{l}1.086 \\
(1.06)\end{array}$ & $\begin{array}{l}1.087 \\
(1.07)\end{array}$ & $\begin{array}{l}1.151^{*} \\
(2.03)\end{array}$ & $\begin{array}{l}1.144^{*} \\
(1.95)\end{array}$ & $\begin{array}{l}1.164^{*} \\
(1.69)\end{array}$ \\
\hline Conciliation & $\begin{array}{l}1.362^{* * *} \\
(5.18)\end{array}$ & $\begin{array}{l}1.408^{* * *} \\
(4.99)\end{array}$ & $\begin{array}{l}1.384^{* * *} \\
(4.74)\end{array}$ & $\begin{array}{l}1.386^{* * *} \\
(4.70)\end{array}$ & $\begin{array}{l}1.348^{* * *} \\
(4.93)\end{array}$ & $\begin{array}{l}1.348^{* * *} \\
(4.94)\end{array}$ & $\begin{array}{l}1.293^{* * *} \\
(3.25)\end{array}$ \\
\hline ULP Filing & $\begin{array}{l}1.343^{* * * *} \\
(4.95)\end{array}$ & $\begin{array}{l}1.384^{* * * *} \\
(4.66)\end{array}$ & $\begin{array}{l}1.377^{* * * *} \\
(4.89)\end{array}$ & $\begin{array}{l}1.400 * * * \\
(4.18)\end{array}$ & $\begin{array}{l}1.351^{* * * *} \\
(4.80)\end{array}$ & $\begin{array}{l}1.341^{* * *} \\
(4.80)\end{array}$ & $\begin{array}{l}1.560^{* * *} \\
(4.18)\end{array}$ \\
\hline FCA Application & $\begin{array}{l}1.369 * * \\
(2.22)\end{array}$ & $\begin{array}{l}1.419^{*} \\
(1.94)\end{array}$ & $\begin{array}{l}1.452^{* *} \\
(2.26)\end{array}$ & $\begin{array}{l}1.495^{* *} \\
(2.23)\end{array}$ & $\begin{array}{l}1.380 * * \\
(2.17)\end{array}$ & $\begin{array}{l}1.345^{* *} \\
(2.02)\end{array}$ & $\begin{array}{l}1.730 * * \\
(2.24)\end{array}$ \\
\hline Log Unit Size & $\begin{array}{l}0.810^{* * *} \\
(9.38)\end{array}$ & $\begin{array}{l}0.805^{* * *} \\
(8.19)\end{array}$ & $\begin{array}{l}0.807^{* * *} \\
(8.31)\end{array}$ & $\begin{array}{l}0.798^{* * *} \\
(5.94)\end{array}$ & $\begin{array}{l}0.806^{* * *} \\
(9.34)\end{array}$ & $\begin{array}{l}0.810^{* * *} \\
(9.25)\end{array}$ & $\begin{array}{l}0.740^{* * *} \\
(6.91)\end{array}$ \\
\hline$\Delta$ Employment & $\begin{array}{l}0.998^{* * *} \\
(2.46)\end{array}$ & $\begin{array}{l}0.999^{*} \\
(1.94)\end{array}$ & $\begin{array}{l}0.998^{* *} \\
(2.08)\end{array}$ & $\begin{array}{l}0.998^{* *} \\
(2.28)\end{array}$ & $\begin{array}{l}0.999 * * \\
(2.09)\end{array}$ & $\begin{array}{l}0.999 * * \\
(2.23)\end{array}$ & $\begin{array}{l}0.999 \\
(0.92)\end{array}$ \\
\hline Type of Unit [Full-Time] & & & & & & & \\
\hline Part-Time & $\begin{array}{l}1.072 \\
(0.35)\end{array}$ & $\begin{array}{l}1.099 \\
(0.39)\end{array}$ & $\begin{array}{l}1.041 \\
(0.17)\end{array}$ & $\begin{array}{l}1.045 \\
(0.18)\end{array}$ & $\begin{array}{l}1.102 \\
(0.47)\end{array}$ & $\begin{array}{l}1.047 \\
(0.23)\end{array}$ & $\begin{array}{l}1.106 \\
(0.31)\end{array}$ \\
\hline Full/Part-Time Mix & $\begin{array}{l}1.161 \\
(1.49)\end{array}$ & $\begin{array}{l}1.239^{*} \\
(1.88)\end{array}$ & $\begin{array}{l}1.241^{* *} \\
(1.98)\end{array}$ & $\begin{array}{l}1.249^{*} \\
(1.93)\end{array}$ & $\begin{array}{l}1.151 \\
(1.35)\end{array}$ & $\begin{array}{l}1.152 \\
(1.38)\end{array}$ & $\begin{array}{l}1.195 \\
(1.18)\end{array}$ \\
\hline Part-Time Not Excluded & $\begin{array}{l}1.105 \\
(1.38)\end{array}$ & $\begin{array}{l}1.086 \\
(1.00)\end{array}$ & $\begin{array}{l}1.097 \\
(1.16)\end{array}$ & $\begin{array}{l}1.106 \\
(1.17)\end{array}$ & $\begin{array}{l}1.087 \\
(1.10)\end{array}$ & $\begin{array}{l}1.094 \\
(1.21)\end{array}$ & $\begin{array}{l}1.107 \\
(0.91)\end{array}$ \\
\hline Government in Power [Liber & & & & & & & \\
\hline Conservative Party & $\begin{array}{l}1.097 \\
(1.39)\end{array}$ & $\begin{array}{l}1.311^{* * *} \\
(4.19)\end{array}$ & $\begin{array}{l}1.265^{* * *} \\
(3.26)\end{array}$ & $\begin{array}{l}1.271^{* * *} \\
(3.19)\end{array}$ & $\begin{array}{l}1.325^{* * *} \\
(4.75)\end{array}$ & $\begin{array}{l}1.005 \\
(0.07)\end{array}$ & $\begin{array}{l}1.102 \\
(1.13)\end{array}$ \\
\hline New Democratic Party & $\begin{array}{l}1.551^{* * *} \\
(3.96)\end{array}$ & $\begin{array}{l}2.052^{* * *} \\
(6.59)\end{array}$ & $\begin{array}{l}1.501^{* * *} \\
(3.34)\end{array}$ & $\begin{array}{l}1.513^{* * *} \\
(3.32)\end{array}$ & $\begin{array}{l}1.172 \\
(1.46)\end{array}$ & $\begin{array}{l}0.712^{* * *} \\
(2.55)\end{array}$ & $\begin{array}{l}0.714^{* *} \\
(2.23)\end{array}$ \\
\hline Legal Regimes [pre-1986 OL & & & & & & & \\
\hline 1986 OLRA & $\begin{array}{l}1.112 \\
(0.61)\end{array}$ & $\begin{array}{l}1.151 \\
(0.72)\end{array}$ & $\begin{array}{l}1.145 \\
(0.75)\end{array}$ & $\begin{array}{l}1.165 \\
(0.74)\end{array}$ & $\begin{array}{l}1.103 \\
(0.52)\end{array}$ & $\begin{array}{l}1.113 \\
(0.61)\end{array}$ & $\begin{array}{l}1.312 \\
(0.88)\end{array}$ \\
\hline 1993 OLRA & $\begin{array}{l}1.016 \\
(0.04)\end{array}$ & $\begin{array}{l}1.035 \\
(0.08)\end{array}$ & $\begin{array}{l}0.988 \\
(0.03)\end{array}$ & $\begin{array}{l}1.011 \\
(0.03)\end{array}$ & $\begin{array}{l}0.996 \\
(0.01)\end{array}$ & $\begin{array}{l}0.969 \\
(0.08)\end{array}$ & $\begin{array}{l}1.331 \\
(0.47)\end{array}$ \\
\hline 1995 OLRA & $\begin{array}{l}1.079 \\
(0.17)\end{array}$ & $\begin{array}{l}1.111 \\
(0.21)\end{array}$ & $\begin{array}{l}1.006 \\
(0.01)\end{array}$ & $\begin{array}{l}1.028 \\
(0.06)\end{array}$ & $\begin{array}{l}1.016 \\
(0.03)\end{array}$ & $\begin{array}{l}0.979 \\
(0.05)\end{array}$ & $\begin{array}{l}1.257 \\
(0.33)\end{array}$ \\
\hline 2000 OLRA & $\begin{array}{l}1.830 \\
(1.08)\end{array}$ & $\begin{array}{l}2.142 \\
(1.22)\end{array}$ & $\begin{array}{l}1.879 \\
(1.03)\end{array}$ & $\begin{array}{l}1.951 \\
(0.99)\end{array}$ & $\begin{array}{l}1.782 \\
(0.98)\end{array}$ & $\begin{array}{l}1.621 \\
(0.84)\end{array}$ & $\begin{array}{l}2.807 \\
(1.08)\end{array}$ \\
\hline Unemployment Rate & $\begin{array}{l}0.917^{* * *} \\
(3.91)\end{array}$ & $\begin{array}{l}0.891^{* * *} \\
(4.73)\end{array}$ & $\begin{array}{l}0.925^{* * *} \\
(3.03)\end{array}$ & $\begin{array}{l}0.923^{* * *} \\
(2.93))\end{array}$ & $\begin{array}{l}1.008 \\
(0.31)\end{array}$ & $\begin{array}{l}1.042 \\
(1.63)\end{array}$ & $\begin{array}{l}1.028 \\
(0.97)\end{array}$ \\
\hline Interval Length & & $\begin{array}{l}1.000 . \\
(1.12)\end{array}$ & $\begin{array}{l}1.000 \\
(0.39) \\
\end{array}$ & $\begin{array}{l}1.0000 \\
(0.48) \\
\end{array}$ & & & \\
\hline Round Dummies & No & No & Yes*** & Yes*** & No & No & No \\
\hline Year Dummies & No & No & No & No & No & Yes*** & Yes*** \\
\hline Heterogeneity Distribution & No & No & No & Yes & No & No & Yes*** \\
\hline All Coefficients $=0$ & $563.96 * * *$ & $487.27 * * *$ & $633.69 * * *$ & $598.95^{* * *}$ & $576.94 * * *$ & $763.07 * * *$ & $569.45 * * *$ \\
\hline Log-Likelihood & -12091.025 & -4704.634 & -4639.560 & -4639.474 & -6481.452 & -6373.282 & -6217.669 \\
\hline Observations & 14016 & 14016 & 14008 & 14008 & 40485 & 40457 & 40457 \\
\hline Bargaining Relationships & 3857 & 3857 & 3857 & 3857 & 3857 & 3857 & 3857 \\
\hline Relationship Dissolutions & 1611 & 1611 & 1611 & 1611 & 1611 & 1611 & 1611 \\
\hline
\end{tabular}




\begin{tabular}{|c|c|c|c|c|c|c|}
\hline \multirow[b]{2}{*}{ Dependent Variable: } & \multicolumn{3}{|c|}{ OML/OLRB Data } & \multicolumn{3}{|c|}{ OML Data } \\
\hline & Work Stoppage & Impasse & $\begin{array}{l}\text { Work Stoppage \& } \\
\text { Mediation }\end{array}$ & Work Stoppage & Impasse & $\begin{array}{l}\text { Work Stoppage \& } \\
\text { Mediation }\end{array}$ \\
\hline Dep. Var.(t-1) $_{\text {. }}$ & $\begin{array}{l}-0.030 \\
(1.43)\end{array}$ & $\begin{array}{l}0.067^{* * *} \\
(3.66)\end{array}$ & $\begin{array}{l}0.084^{* * *} \\
(4.03)\end{array}$ & $\begin{array}{l}-0.006 \\
(0.58)\end{array}$ & $\begin{array}{l}0.095^{* * *} \\
(11.04)\end{array}$ & $\begin{array}{l}0.097 * * * \\
(9.95)\end{array}$ \\
\hline Log Unit Size & $\begin{array}{l}0.020^{* *} \\
(2.03)\end{array}$ & $\begin{array}{l}0.034^{*} \\
(1.82)\end{array}$ & $\begin{array}{l}0.032^{*} \\
(1.88)\end{array}$ & $\begin{array}{l}0.011^{* * *} \\
(3.17)\end{array}$ & $\begin{array}{l}0.055^{* * * *} \\
(6.79)\end{array}$ & $\begin{array}{l}0.039 * * * \\
(5.50)\end{array}$ \\
\hline$\Delta$ Employment & $\begin{array}{l}0.000 \\
(0.31)\end{array}$ & $\begin{array}{l}0.000 \\
(0.18)\end{array}$ & $\begin{array}{l}0.000 * * * \\
(3.26)\end{array}$ & $\begin{array}{l}0.000 \\
(0.67)\end{array}$ & $\begin{array}{l}-0.000 \\
(1.03)\end{array}$ & $\begin{array}{l}-0.000 \\
(0.90)\end{array}$ \\
\hline \multicolumn{7}{|l|}{ Type of Unit [Full-Time] } \\
\hline Part-Time & $\begin{array}{l}0.037 \\
(0.99)\end{array}$ & $\begin{array}{l}0.078 \\
(0.52)\end{array}$ & $\begin{array}{l}-0.079 \\
(1.09)\end{array}$ & $\begin{array}{l}0.018 \\
(0.45)\end{array}$ & $\begin{array}{l}0.090 \\
(1.13)\end{array}$ & $\begin{array}{l}0.045 \\
(0.67)\end{array}$ \\
\hline Full /Part-Time Mix & $\begin{array}{l}0.050^{*} \\
(1.86)\end{array}$ & $\begin{array}{l}-0.026 \\
(0.59)\end{array}$ & $\begin{array}{l}-0.012 \\
(0.31)\end{array}$ & $\begin{array}{l}0.021^{*} \\
(1.85)\end{array}$ & $\begin{array}{l}0.005 \\
(0.20)\end{array}$ & $\begin{array}{l}0.005 \\
(0.24)\end{array}$ \\
\hline Part-Time Not Excluded & $\begin{array}{l}0.001 \\
(0.07)\end{array}$ & $\begin{array}{l}-0.046 \\
(1.42)\end{array}$ & $\begin{array}{l}-0.021 \\
(0.70)\end{array}$ & $\begin{array}{l}-0.013 \\
(1.50)\end{array}$ & $\begin{array}{l}-0.005 \\
(0.31)\end{array}$ & $\begin{array}{l}-0.008 \\
(0.48)\end{array}$ \\
\hline \multicolumn{7}{|l|}{ Prior Contract Length [1 Year] } \\
\hline 2 Years & $\begin{array}{l}0.017^{*} \\
(1.71)\end{array}$ & $\begin{array}{l}-0.040^{*} \\
(1.67)\end{array}$ & $\begin{array}{l}0.009 \\
(0.44)\end{array}$ & $\begin{array}{l}0.000 \\
(0.03)\end{array}$ & $\begin{array}{l}-0.022^{* *} \\
(2.03)\end{array}$ & $\begin{array}{l}-0.014 \\
(1.56)\end{array}$ \\
\hline $2+$ Years & $\begin{array}{l}-0.010 \\
(0.94)\end{array}$ & $\begin{array}{l}-0.014 \\
(0.56)\end{array}$ & $\begin{array}{l}0.006 \\
(0.27)\end{array}$ & $\begin{array}{l}-0.013^{* *} \\
(2.59)\end{array}$ & $\begin{array}{l}0.002 \\
(0.15)\end{array}$ & $\begin{array}{l}0.001 \\
(0.10)\end{array}$ \\
\hline \multicolumn{7}{|l|}{ Government in Power [Liberal] } \\
\hline Conservative Party & $\begin{array}{l}0.013 \\
(0.60)\end{array}$ & $\begin{array}{l}-0.050 \\
(0.80)\end{array}$ & $\begin{array}{l}-0.055 \\
(0.98)\end{array}$ & $\begin{array}{l}0.002 \\
(0.25)\end{array}$ & $\begin{array}{l}-0.035^{*} \\
(1.73)\end{array}$ & $\begin{array}{l}-0.031^{*} \\
(1.76)\end{array}$ \\
\hline New Democratic Party & $\begin{array}{l}0.038 \\
(1.37)\end{array}$ & $\begin{array}{l}-0.030 \\
(0.46)\end{array}$ & $\begin{array}{l}-0.008 \\
(0.13)\end{array}$ & $\begin{array}{l}0.004 \\
(0.40)\end{array}$ & $\begin{array}{l}-0.053^{* *} \\
(2.45)\end{array}$ & $\begin{array}{l}-0.015 \\
(0.73)\end{array}$ \\
\hline Unemployment Rate & $\begin{array}{l}0.060 \\
(0.52)\end{array}$ & $\begin{array}{l}0.423 \\
(1.45)\end{array}$ & $\begin{array}{l}1.348^{* * *} \\
(5.41)\end{array}$ & $\begin{array}{l}-0.019^{* * *} \\
(3.00)\end{array}$ & $\begin{array}{l}0.010 \\
(0.75)\end{array}$ & $\begin{array}{l}-0.004 \\
(0.34)\end{array}$ \\
\hline Constant & $\begin{array}{l}-0.002 \\
(0.22) \\
\end{array}$ & $\begin{array}{l}-0.006 \\
(0.33) \\
\end{array}$ & $\begin{array}{l}-0.011 \\
(0.75)\end{array}$ & $\begin{array}{l}0.001 \\
(0.30)\end{array}$ & $\begin{array}{l}0.024 * * * \\
(3.16)\end{array}$ & $\begin{array}{l}0.000 \\
(0.01)\end{array}$ \\
\hline All Coefficients $=0$ & $76.49 * * *$ & $94.28 * * *$ & $100806.61^{* * *}$ & $151.59 * * *$ & $352.30 * * *$ & $340.86^{* * *}$ \\
\hline Observations & 7348 & 7348 & 7348 & 36267 & 36267 & 36267 \\
\hline Relationships & 2120 & 2120 & 2120 & 7165 & 7165 & 7165 \\
\hline Mean of DV & 0.031 & 0.549 & 0.243 & 0.038 & 0.504 & 0.246 \\
\hline
\end{tabular}

\begin{tabular}{|c|c|c|c|c|c|c|}
\hline \multirow[b]{2}{*}{ Dependent Variable: } & \multicolumn{3}{|c|}{ OML/OLRB Data } & \multicolumn{3}{|c|}{ OML Data } \\
\hline & Work Stoppage & Impasse & $\begin{array}{l}\text { Work Stoppage \& } \\
\text { Mediation }\end{array}$ & Work Stoppage & Impasse & $\begin{array}{l}\text { Work Stoppage } \\
\& \text { Mediation }\end{array}$ \\
\hline Dep. Var.(t-1) & $\begin{array}{l}-0.018 \\
(0.69)\end{array}$ & $\begin{array}{l}0.077^{* * *} \\
(2.80)\end{array}$ & $\begin{array}{l}0.186 * * * \\
(6.35)\end{array}$ & $\begin{array}{l}-0.004 \\
(0.33)\end{array}$ & $\begin{array}{l}0.128^{* * *} \\
(11.420\end{array}$ & $\begin{array}{l}0.181^{* * *} \\
(14.52)\end{array}$ \\
\hline Dep. Var.(t-2) & $\begin{array}{l}0.041^{*} \\
(1.86)\end{array}$ & $\begin{array}{l}0.008 \\
(0.37)\end{array}$ & $\begin{array}{l}0.091^{* * *} \\
(4.14)\end{array}$ & $\begin{array}{l}0.008 \\
(0.74)\end{array}$ & $\begin{array}{l}0.033^{* * *} \\
(3.59)\end{array}$ & $\begin{array}{l}0.065^{* * *} \\
(6.52)\end{array}$ \\
\hline All Coefficients $=0$ & 47.30 & $68.42^{* *}$ & $14309.27^{* * *}$ & $101.21^{* * *}$ & $345.42^{* * *}$ & $380.97 * * *$ \\
\hline Observations & 5228 & 5228 & 5228 & 29205 & 29205 & 29205 \\
\hline Relationships & 1595 & 1595 & 1595 & 6065 & 6065 & 6065 \\
\hline Mean of DV & 0.029 & 0.535 & 0.230 & 0.034 & 0.498 & 0.243 \\
\hline
\end{tabular}

